\title{
A RECORD OF PINK SALMON, ONCORHYNCHUS GORBUSCHA (ACTINOPTERYGII, SALMONIFORMES, SALMONIDAE), IN THE REVELVA RIVER, HORNSUND AREA (SW SPITSBERGEN)
}

\author{
Andrzej WITKOWSKI ${ }^{1 *}$ and Piotr GŁOWACKI ${ }^{2}$ \\ ${ }^{1}$ Wrockaw University, Museum of Natural History, Wroctaw, Poland \\ ${ }^{2}$ Polish Academy of Sciences, Institute of Geophysics, Warsaw, Poland
}

Witkowski A., Głowacki P. 2010. A record of pink salmon, Oncorhynchus gorbuscha (Actinopterygii, Salmoniformes, Salmonidae), in the Revelva River, Hornsund area (SW Spitsbergen). Acta Ichthyol. Piscat. 40 (1): 87-89.

\begin{abstract}
In 2007-2008 the pink salmon, Oncorhynchus gorbuscha, was observed to attempt spawning migration up the Revelva River. The possibility of natural spawning of this alien species in rivers and lakes of Spitsbergen, as well as the risk of its natural hybridization with the native Arctic charr, Salvelinus alpinus, are discussed.
\end{abstract}

Keywords: Spitsbergen, introduction, pink salmon, alien fish, non-indigenous fish

Fish diversity of the seas surrounding the Svalbard Archipelago (Spitsbergen) is small; this pertains especially to the coastal waters and fjords (Hofstein 1919, Hognestadt 1963, Andriâšev 1954, Matišev 1986). Węsławski and Kuliński (1989) report only 14 fish species from the Hornsund Fjord.

The native salmonids (Salmonidae) in the region are represented only by the Arctic charr, Salvelinus alpinus, (see: Radziun 1993, Hansen and Overrein 2000). According to Gullestad (1971) and Węsławski et al. (1990) the pink salmon (Oncorhynchus gorbuscha) is also sporadically encountered in the coastal waters of the West Spitsbergen.

This species is native to the northern Pacific basin in Russia, Japan, North China, and North America. During the period between 1956 and 1978, over 200 million eggs were shipped from the Sakhalin Islands to the Kola Peninsula (Murmansk region) and the White Sea. Adults are known to return regularly to the Tenojoki and Näätämöjoki Rivers (Finland, Norway) (Kottelat and Freyhof 2007). The pink salmon is also occasionally found in the North Sea and north-western Atlantic as a result of introduction to the American Great Lakes, Labrador, Newfoundland and Nova Scotia (Scott and Crossman 1973), or as strayers from the White Sea.

In 2007 and 2008 a few individuals of the species were observed in the mouth section (ca. $100 \mathrm{~m}$ ) of the Revelva River (lat $77^{\circ} 00^{\prime} \mathrm{N}$, long $15^{\circ} 38^{\prime} \mathrm{E}$; Hornsund region, SW Spitsbergen). Together with the Arctic charr, they were attempting to migrate upstream from the sea. Two specimens were caught, with total lengths of $533 \mathrm{~mm}$ (16 Aug. 2007) and $561 \mathrm{~mm}$ (3 Sept. 2008).

The first one was male (Fig.1), with well developed secondary sexual characters, such as clearly marked hump, enlarged head, and jaws with large teeth. The testes were well developed. Coloration was still marine-the dorsal surface steel blue, the sides silver with a faint pink hue. The back, adipose fin and both lobes of the caudal fin had black spots. The second fish was a female (Fig. 2), of pale pink colour with numerous brown streaks running dorsoventrally. This indicates that the fish had already spent some time in freshwater. The specimen has been deposited at the Museum of Natural History, Wrocław University (MNHWU-FC 082 993).

The state of the gonads and the changes in body proportions and coloration (into spawning mode) of the individuals migrating upstream indicate a spawning attempt. Probably the numbers of the pink salmon in the waters surrounding Spitsbergen are too small to form spawning schools and reproduce naturally. This may be the reason why no juvenile stages of the species were ever noted among the fry of Arctic charr in the Revelva River and Lake Revvatnet (Witkowski et al. 2008). However, spawning might be expected in some western regions of the Svalbard Archipelago. Because of the small numbers of pink salmon, the presence of its hybrids with the autochthonous Arctic charr is likely, since species of the genera Salvelinus and Oncorhynchus are capable of hybridization (Berst et al. 1980, Dobosz and Goryczko 1988). The hybridization may be favoured by the fact that the two

\footnotetext{
" Correspondence: Prof. dr hab. Andrzej Witkowski, Wrocław University, Museum of Natural History, ul. Sienkiewicza 21, 50-335 Wrocław, Poland, phone: + 487137541 53, e-mail: a.witkowski@biol.uni.wroc.pl.
} 

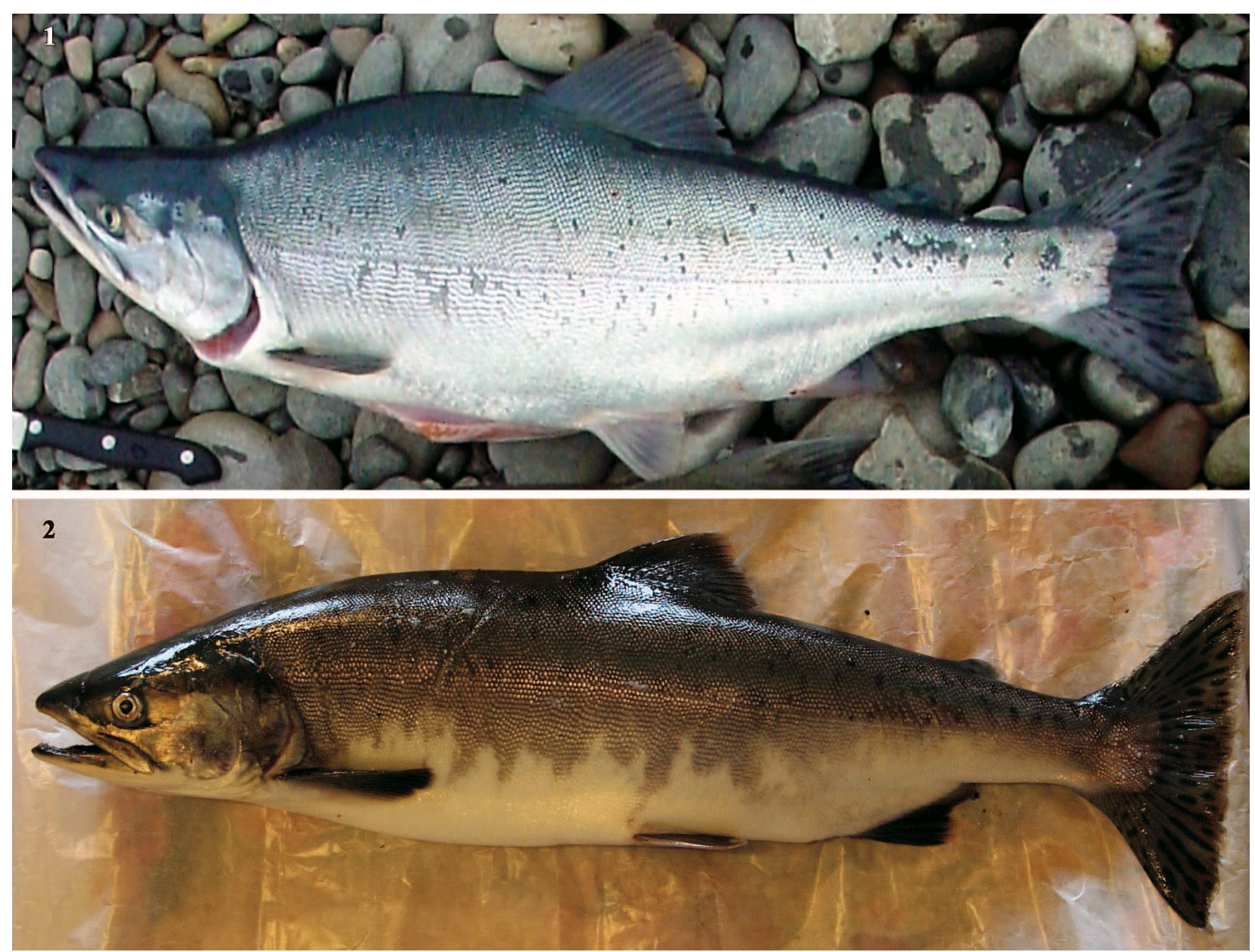

Figs. 1-2. Pink salmon, Oncorhynchus gorbuscha, from the Revelva River; Fig. 1. Male (photo Piotr Głowacki); Fig. 2. Female (photo Witold Kaszkin)

species spawn at similar times and in similar habitats (Scott and Crossman 1973, Smirnov 1975).

\section{ACKNOWLEDGEMENTS}

We thank the Sysselmann (Governor) of the Svalbard Archipelago for the permission to conduct ichthyological studies in the South Spitsbergen National Park. We are grateful to Mr. Lech Witkowski (Polish Polar Station at Hornsund) for his help with collecting and preservation of the specimens.

The paper was prepared within the programme „Biodiversity of the Arctic ecosystems”.

\section{REFERENCES}

Andriâšev A.P. [Andriiashev A.P.] 1954. Ryby severnyh morej SSSR. [Fishes of the northern seas of the SSSR.] Izdatel'stvo AN SSSR, Moskva-Leningrad. [In Russian.]

Berst A.H., Ihssen P.E., Spangler G.R., Ayles G.B., Martin G.W. 1980. The splake, a hybrid charr Salvelinus namaycush $\times$ S. fontinalis. Pp. 841-887. In: Balon E.K. (ed.) Charrs. Salmonid fishes of the genus Salvelinus. Dr W. Junk bv Publishers, the Hague, the Netherlands.

Dobosz S., Goryczko K. 1988. Effect of polyploidization on survival of sea, brook and rainbow trout hybrids during incubation and early feeding period. Acta Ichthyologica et Piscatoria 18 (2): 19-22.

Gullestad N. 1971. Pukkellaks (Oncorhynchus gorbuscha) pa Svalbard sommeren 1971. [Pink Salmon (Oncorhynchus gorbuscha) in Svalbard summer 1971.] Norsk Polarinstitutt, Årbok 1971: 121. [In Norwegian.]

Hansen J.R., Overrein Ø. 2000. Røye på Svalbard og Jan Mayen. [Arctic charr on the Spitsbergen and Jan Mayen.] Norsk Polarinstitutt, Raportserie 114: 1-42. [In Norwegian.]

Hofstein N. 1919. Zoologische Ergebnisse der Schwedischen Expedition nach Spitsbergen 1908. Teil III. Die Fische des Eisfjordes. Kungliga Svenska Vetenskaps-Akademiens Handlingar 54: 1-129.

Hognestadt P.T. 1963. Contribution to the fish fauna of Isfjorden. Acta Borealia 18: 1-36.

Kottelat M., Freyhof J. 2007. Handbook of european freshwater fishes. Cornol, Switzerland.

Matišev G.G. [Matishev G.G.] (ed.) 1986. Ihtiofauna i uslovija ee suščestvovanja $\mathrm{v}$ Barentsovom morje. [Ichthyofauna and its occurrence conditions in the Barents Sea.] Izdatel'stvo AN SSSR, Apatyty. [In Russian.]

Radziun K. 1993. Observations on the Arctic charr, Salvelinus alpinus (L., 1758) from the Hornsund region (Vest Spitsbergen) in 1985-1987. Acta Ichthyologica et Piscatoria 33 (suppl.): 7-22. 
Scott W.B., Crossman E.J. 1973. Freshwater fishes of Canada. Bulletin of the Fisheries Research Board of Canada 184: $1-966$.

Smirnov A.I. 1975. Biologia, razmnoženije i razvitie tihokeanskih lososiej. [Biology, reproduction and development of Pacific salmons.] Izdatel'stvo Moskovskogo Universiteta, Moskva. [In Russian.]

Węsławski J.M., Kuliński W. 1989. Notes on fishes in Hornsund fjord area (Spitsbergen). Polish Polar Research 10 (2): 241-250.

Węsławski J.M., Linkowski T., Herra T. 1990. Fishes of South Spitsbergen. Pp. 69-77 and 99-194. In: Klekowski R.Z.,
Węsławski J.M. (eds.) Atlas of the marine fauna of southern Spitsbergen. Vol. 1. Vertebrates. Ossolineum, Wrocław.

Witkowski A., Kotusz J., Kusznierz J., Popiołek M. 2008. Summer dynamics of density and biomass of the Arctic charr, Salvelinus alpinus (L.), in a polar stream (SW Spitsbergen). Polish Polar Research 29 (3): 237-243.

Received: 4 June 2009 Accepted: 14 December 2009 Published electronically: 25 June 2010 